\title{
Investigating the Factors Impacting the Student Satisfaction With the Universities: A Comparative Study of Malaysia and Pakistan
}

\author{
Faisal Khalil-Ur-Rehman* \\ Limkokwing University of Creative Technology, Malaysia \\ Muhammad Farooq \\ Limkokwing University of Creative Technology, Malaysia \\ Tansholpan Bekmyrza \\ Universiti Kuala Lumpur, Malaysia \\ Waqar Younas \\ Limkokwing University of Creative Technology, Malaysia \\ Valliappan Raju \\ Limkokwing University of Creative Technology, Malaysia
}

\begin{abstract}
The purpose of this study is to investigate the factors impacting the student satisfaction with the public and private universities of Malaysia and Pakistan, which are countries representing South/South-East Asia in cross-culture perspective. The study has applied a quantitative survey design guided by five hypotheses. A questionnaire was distributed among the students of private and public universities. A conceptual framework has been developed based on the modification of Student Satisfaction Index (SSI) model to measure the satisfaction of students from different aspects, such as university image, university location, quality of academic staff, university facilities, student expectation, overall student satisfaction. The research method used was a survey-based questionnaire that consisted of a total of 396 responses from the university students. The data were analyzed with SPSS and SmartPLS 3; the results indicate that when the comparison was made separately between private and public universities of Malaysia and Pakistan. The comparative statistical score was obtained using independent sample t-Test, the university facilities of Malaysian universities resulted higher than universities in Pakistan. Therefore, the independent sample ttest results conclude that the university facilities have a significant evidence $(\mathrm{p}=0.00)$ to support our research findings that university facilities do affect the student satisfaction more in Malaysia (mean=4.1788) than Pakistan (mean =3.7212) and the research hypothesis is significant that there is a significant difference in student satisfaction towards university facilities in Malaysia and Pakistan. Similarly, the quality of academic staff $(\mathrm{p}=0.035)$ has a significant effect on student satisfaction in Malaysia (mean=3.8283) and Pakistan (mean=3.6641). Furthermore, this leads the student expectation and overall student satisfaction level of Malaysia students are higher than students in Pakistan. However, student satisfaction level on university image and university location in Malaysia and Pakistan do not differ. The study is useful for university management to improve university students satisfaction. The future researchers are recommended further explore demographic and cultural variables impact on student satisfaction.
\end{abstract}

Keywords: Student satisfaction; University image; Student expectation; University facilities; Quality of academic staff.

\section{(9) (1) CC BY: Creative Commons Attribution License 4.0}

\section{Introduction}

In recent years, the higher education industry has evolved, and student expectations towards universities have increased (Lin, Salazar, \& Wu, 2018). Student expectation from higher education institutions includes The faculty relationship with the students, activities and facilities provided to students and different level of satisfaction related to teaching and learning. These expectations directly impact the overall student satisfaction (Arambewela \& Hall, 2009; Lin et al., 2018). Educational globalization has evolved many public and private universities in Asia, which led competition among local and international universities (Temizer and Turkyilmaz, 2012; Ulyani et al., 2011).

Global market forced higher educational institutes to raise their standards in this competitive era. Services like teaching quality, facilities and support in studies are key factors that will have enormous impact on student satisfaction level. Addition to this student career counseling during their studies have a considerable impact on the student's career (Napitupulu et al., 2018).

The core objective of this study is to measure the factors that are impacting student satisfaction level in Malaysia and Pakistan. The research will analyze various variables (university image, facilities, location and quality of academic staff) through the mediating role of student expectation result on overall student satisfaction in the context of Malaysia and Pakistan. The Research will also analyze the impact of the specific variable on country level. European Customer Satisfaction Index (ECSI) is proposed from Student Satisfaction Index (SSI) to measure 
the comparative satisfaction level of students from Malaysia and Pakistan (Brown and Mazzarol, 2009; Mansori et al., 2014).

Student satisfaction index model has been used previously to measure the different variables, The SSI model will be used for comparative study in the context of Malaysia and Pakistan. This research will help the universities in Pakistan to analyze the factors that have been proved to work in Malaysia, also the SSI model constructs will be applied in both countries to analyze the impact of specific latent construct and measurement in the context of comparative study (Ijaz et al., 2011; Subrahmanyam, 2017).

\section{Literature Review}

Customer satisfaction is of the widly studied aspect in marketing literatur. In broad defination of customer the universty students are also customers of private universties. Students are the reason why these universiteis exisit, Therefore student satisfaction and quality service should goal of these busiensses (Universities) (Buzdar et al., 2016) e Hence in this study the conceptual framework applied is the modification of Student Satisfaction Index (SSI) Model. The SSI model is a structural model based on the assumptions that expectation of the students, perceived value, perceived quality, an image of a firm have a direct impact on the satisfaction (Saleem et al., 2017). This study is the continuation of earlier conduct study which recommended the future researchers to study the University facilities and location are newly tested variables in higher education literature that need to validate in the comparative study of Malaysia and Pakistan context (Khalil-ur-rehman and Farooq, 2018).

There are total of 162 HEC recognized universities in Pakistan, whereby 66 universities are private universities (Turkyilmaz et al., 2018). Student satisfaction peaked one of the highly focused concern for many universities across the world from last decade. Further analyze the literature review and propose a formwork solution to explain the concept in-depth. Reviewing different literatures related to student satisfaction level at university level has enabled to understand and analyze different variables in the context of Malaysia and Pakistan. There are not many researches to review the constructs that have high impact in this comparative study.

Student satisfaction leads towards student loyalty; which certain universities fail to provide. Student satisfaction pillars carries many factors to build student loyalty to institution that may include university image, facilities, teaching quality, career counseling, student expectations, scholarship and these pillars have tremendous impact on overall student satisfaction (Teo and Wong, 2013; Weerasinghe and Fernando, 2018).

Teaching facilities, research and university activities have a high impact on student satisfaction level. The evaluation of universities has grown since the private universities came into the competition. In this transformative era the educational standards have raised in many aspects, the private universities have emerged with educational standards. Universities standards have raised in Malaysian universities more than a universities in Pakistan (Amin and Isa, 2008; Turkyilmaz et al., 2018).

International students are playing a major role in developing Malaysian economy. Education in Malaysia is relatively cheap compare to European countries, which leads Malaysian Government to internationalize the higher education sector globally (The Malaysian Higher Education). Malaysian Government is devoted to enhanced the education quality and facilities in Malaysia to attract more international students. According to Ali et al. (2016) service quality to students improves and enhance the educational overall student satisfaction to students in Malaysia. International student market growth in Pakistan is not very well developed compare to Malaysia. This research will highlight the specific variable impact in the context of Malaysia and Pakistan.

H1: University location has a positive and significant relationship on overall student satisfaction in Malaysia and Pakistan.

University location is measured based on the availability of accommodation, security, transportation, and employment opportunity. Hanssen and Solvoll (2015) investigated that the university location has a positive and relatively massive impact on overall student satisfaction. Similarly, the security which relates to the location has a positive impact on female students (Weerasinghe and Fernando, 2018).

H2: There is a significant positive relationship between the quality of academic staff and Student expectations.

Quality of academic staff has a statically significant impact on the overall student satisfaction (Ball and Chik, 2001; Eva et al., 2015). Which includes flexible study timetable, the academic quality of teaching, academic staff qualification and teaching skills (Hussein and Abdul, 2012; Lam, 2010).

H3: University image has a positive and significant relationship on student expectation.

The brand name and university reputation and ranking refer to the university image. Tsedzah and ObuobisaDarko (2015) investigated that the university image has statically effect on student loyalty.

H4: There is a significant positive relationship between university facilities and student expectations.

University facilities include the daily operations (digital library, Wi-Fi, common study area, computer labs) to achieve student satisfaction (Zhai et al., 2017). Universities across the world especially in Singapore are providing high tech support and facilities to students, which is helping the students to complete the major projects and findings from university and Government (Awang et al., 2010; Teo et al., 2009).

H5: Student expectation has a positive and significant impact on overall student satisfaction.

Student expectation is playing a mediating role in this research; it has a positive and significant impact on the overall student satisfaction. According to Subrahmanyam (2017); Sultan and Wong (2013) student expectation has an active mediating role in the research area of student satisfaction. 


\subsection{Conceptual Framework}

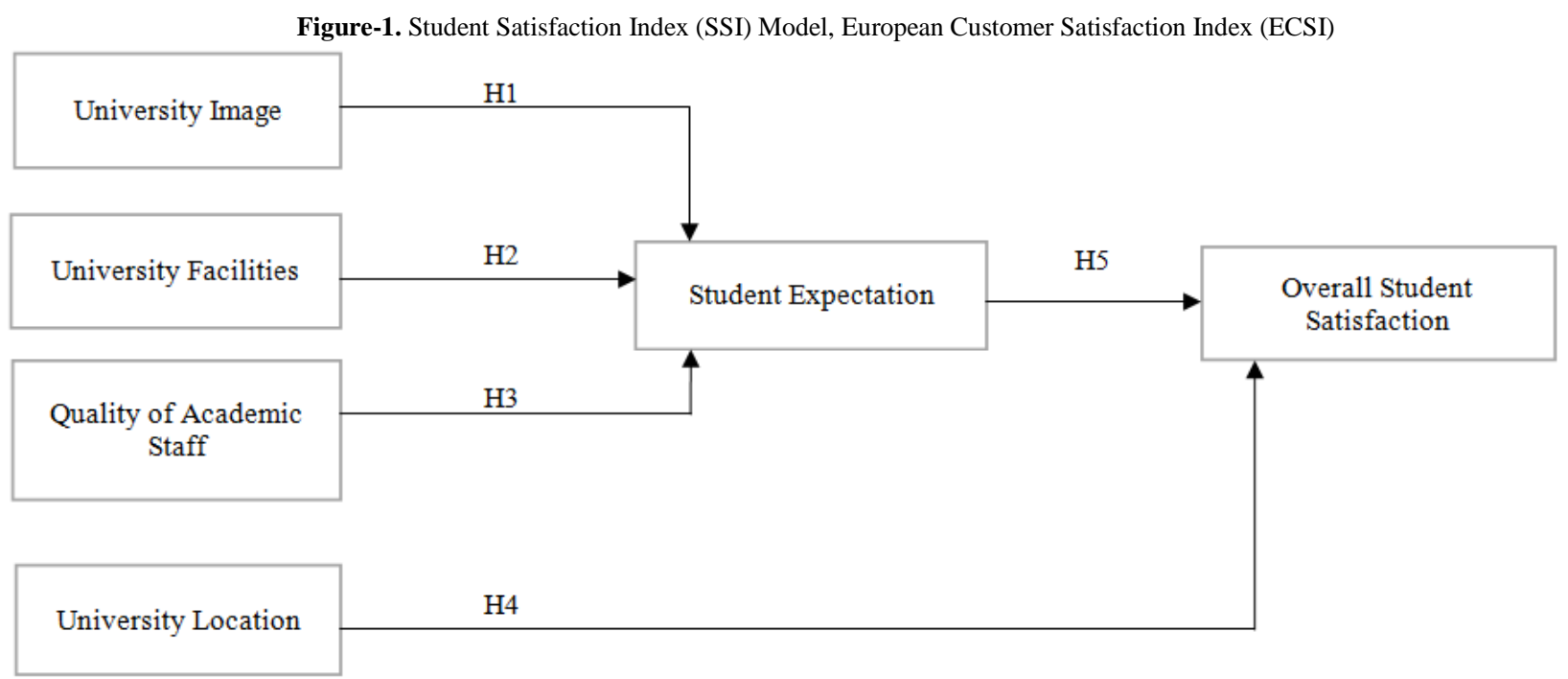

The student satisfaction Index Model ha been studied in context together with European Customer Satisfaction Index (ECSI). Alves and Raposo (2009) I ndicated that knowing the student satisfaction process with reliable and valid construct will make educational institutions threshold the student satisfaction (Alrasheedi and Capretz, 2013). It is very important to measure the right constructs of student satisfaction in order to be able to enhance the quality of the institution (Alshehri, 2017; Turkyilmaz et al., 2018). Focusing on to enhance the quality of education and provide all the necessity facilities to the student will make the institutions re-build their organizational structure to prioritize the significant factor that related to student satisfaction, as for the end of the day student is the primary customer to university (Ahmad, 2015).

According to Ajayi (2015) the complexity of student satisfaction analyses many dimensions of the educational aspects. Student satisfaction may have many expectations and priorities, which may range from favorability, learning, facilities, course fees, accommodation, university image, career counseling, university location and many more (Choy et al., 2017). Most of-of the outcomes of student satisfaction are related to service quality and factors related to it Al-hawari and Mouakket (2010); Khan and Nawaz (2011).

\section{Methodology}

This is quantiatitative study, The researchers has opted the the cross sectional data collection approach get primary data from the university students of Malaysia and Pakistan. Based literature a conceptual framework was slected. To confirm the model validity and reliability structural equentioanl model technique has been used in the study. The SEM is a theoretical construct study to analyze data from a specific population (Saleem et al., 2017) (Hox, n.d.).

Referral sampling technique have been used to collect the data from respondent (Riera et al., 2018). The respondents were university students from Malaysia and Pakistan.

\subsection{Sample Size}

According to Krejcie and Morgan (1970), for the N (1,000,000) number population 384 sample size will represent the $\mathrm{N}$ number of population. For this research, the sample size of 396 respondents were selected to collect responses from all the universities of Malaysia and Pakistan.

\subsection{Data Collection}

Data collection was carried out on Google forms platform, survey link was shared to 68 universities in Malaysia and 162 universities in Pakistan. The questionnaire consisted on 2 sections, demographic and variables related question. Since the number of universities are more in Pakistan majority of respondents (264) responses will be collected from Pakistan and 132 respondents from Malaysia.

\section{Results and Findings}

In this research total 396 responses (326 male and 70 female) were collected by referral sampling technique. As mentioned in table 1, mainly 326 respondents $82 \%$ were male and 70 respondents $18 \%$ were female. Furthermore, the respondents belong to the universities from Malaysia and Pakistan. The majority $67 \%$ of the respondents from Pakistan and $33 \%$ of the respondents were from Malaysia. It is because the number of universities are more than the number of universities in Malaysia. The number of universities in Pakistan are 162 and the number of universities in Malaysia are 68. 
Most of the respondents $242(61 \%)$ were from age 18-25 years followed by $130(33 \%)$ respondents were age 2635 year, $22(5.5 \%)$ respondents were $36-45$ and remaining $2(0.5 \%)$ respondents were 46 and above age range. The results indicate that the most of the respondents $242(61 \%)$ were young as shown in Table 1.

The count for majority respondents were undergraduate $48 \%$, whereby graduate $24 \%$ and postgraduate $28 \%$ respondents.

Table-1. Demographic Profile

\begin{tabular}{l|l|l}
\hline Gender & Count of Respondents & $\mathbf{\%}$ \\
\hline Male & $\mathbf{3 2 6}$ & $\mathbf{8 2 \%}$ \\
\hline Female & $\mathbf{7 0}$ & $\mathbf{1 8 \%}$ \\
\hline Total & $\mathbf{3 9 6}$ & $\begin{array}{l}\mathbf{1 0 0} \\
\mathbf{\%}\end{array}$ \\
\hline Age & Count of Respondents & $\mathbf{\%}$ \\
\hline 18 to 25 & $\mathbf{2 4 2}$ & $\mathbf{6 1 \%}$ \\
\hline 36 to 35 & $\mathbf{1 3 0}$ & $\mathbf{3 3 \%}$ \\
\hline 46 and Above & $\mathbf{2 2}$ & $\mathbf{5 . 5 \%}$ \\
\hline Total & $\mathbf{2}$ & $\mathbf{0 . 5 \%}$ \\
\hline Country of Study & $\mathbf{3 9 6}$ & $\mathbf{1 0 0}$ \\
\hline Pakistan & Count of respondents & $\mathbf{\%}$ \\
\hline Malaysia & $\mathbf{2 6 4}$ & $\mathbf{6 7 \%}$ \\
\hline Total & $\mathbf{1 3 2}$ & $\mathbf{3 3 \%}$ \\
\hline Education Level & $\mathbf{3 9 6}$ & $\mathbf{1 0 0}$ \\
\hline Undergraduate & Count of respondents & $\mathbf{\%}$ \\
\hline Graduate & $\mathbf{1 9 0}$ & $\mathbf{4 8 \%}$ \\
\hline Postgraduate & $\mathbf{9 6}$ & $\mathbf{2 4 \%}$ \\
\hline Total & $\mathbf{1 1 0}$ & $\mathbf{2 8 \%}$ \\
\hline & $\mathbf{3 9 6}$ & $\mathbf{1 0 0}$ \\
\hline
\end{tabular}

The outer loading values in table 2 is indicating the indicators reliability. According to (Hair, Black, Babin, \& Anderson, 2017) the indicators reliability value should be greater than $>0.708$. Also Byrne (2016) argues that outer loading value greater than $>0.6$ is acceptable. Overall, the outer loading values in table 2 are consistent and reliable.

The $\mathrm{R}^{2}$ value 0.67 in table 2 indicates the overall impact of independents variables (University Image, University Location, Quality of Academic Staff, University Facilities) have a 67\% of impact on dependent variables. Mediator (Student expectation) has a huge impact $58 \%$ on dependent variable. The $\mathrm{F}^{2}$ value for Quality of Academic Staff has an impact of $30 \%$ on $\mathrm{R}^{2}$, which indicates that the quality of academic staff has a huge impact on student satisfaction in both countries Malaysia and Pakistan.

Furthermore, $\mathrm{F}^{2}$ value of university facilities indicates that the University facilities matters least than other variables. 1978).

As shown in table 2 Cronbach Alpha was found reliable, as it reaches the minimum threshold of 0.70 (Nunnally,

Table-2. Construct Validity and Reliability

\begin{tabular}{|c|c|c|c|c|c|}
\hline Items & Outer Loadings & Cronbach's Alpha & AVE & $\mathbf{R}^{2}$ & $\mathbf{F}^{2}$ \\
\hline \multicolumn{6}{|l|}{ University Image } \\
\hline Is reliable & 0.872 & \multirow{4}{*}{0.82} & \multirow{4}{*}{0.701} & & \multirow{4}{*}{0.195} \\
\hline Is professional & 0.909 & & & & \\
\hline Is contributing to the society & 0.857 & & & & \\
\hline Is recognised & 0.695 & & & & \\
\hline \multicolumn{2}{|l|}{ University Location } & \multirow{5}{*}{0.80} & \multirow{5}{*}{0.543} & & \multirow{5}{*}{0.231} \\
\hline Has good accommodation & 0.834 & & & & \\
\hline Has a convenient transport system & 0.727 & & & & \\
\hline Students have high employability & 0.722 & & & & \\
\hline Area is safe & 0.653 & & & & \\
\hline \multicolumn{2}{|l|}{ Quality of Academic Staff } & \multirow{4}{*}{0.88} & \multirow{4}{*}{0.829} & & \multirow{4}{*}{0.314} \\
\hline $\begin{array}{c}\text { Academic staff have a broader } \\
\text { knowledge }\end{array}$ & 0.908 & & & & \\
\hline Provides quality of delivery & 0.937 & & & & \\
\hline Provides effective support & 0.886 & & & & \\
\hline \multicolumn{2}{|l|}{ University Facilities } & \multirow[b]{2}{*}{0.84} & \multirow[b]{2}{*}{0.679} & & \multirow[b]{2}{*}{0.065} \\
\hline $\begin{array}{l}\text { Facilities benches and chairs in the } \\
\text { classroom }\end{array}$ & 0.810 & & & & \\
\hline
\end{tabular}




\begin{tabular}{|c|c|c|c|c|c|}
\hline Has a good air-conditioning system & 0.853 & & & & \\
\hline $\begin{array}{l}\text { Have an available books, e-library and } \\
\text { reference journals }\end{array}$ & 0.786 & & & & \\
\hline Wifi network facilities on campus & 0.848 & & & & \\
\hline $\begin{array}{l}\text { Provides computers and multimedia } \\
\text { facilities in the classroom }\end{array}$ & 0.821 & & & & \\
\hline Student Expectations & & \multirow{5}{*}{0.86} & \multirow{5}{*}{0.763} & & \multirow{5}{*}{0.589} \\
\hline $\begin{array}{l}\text { The expectation of an educational } \\
\text { quality }\end{array}$ & 0.880 & & & & \\
\hline The expectation of social environment & 0.868 & & & & \\
\hline $\begin{array}{l}\text { Fulfilment of educational and career } \\
\text { goals }\end{array}$ & 0.885 & & & & \\
\hline $\begin{array}{l}\text { Management and administrative } \\
\text { excellence }\end{array}$ & 0.859 & & & & \\
\hline Overall Student Satisfaction & & \multirow{4}{*}{0.87} & \multirow{4}{*}{0.752} & \multirow{4}{*}{0.671} & \\
\hline $\begin{array}{l}\text { I have the intention of selecting the } \\
\text { same university }\end{array}$ & 0.890 & & & & \\
\hline I recommend my university to others & 0.899 & & & & \\
\hline $\begin{array}{l}\text { My intention is to switch the } \\
\text { university when possible }\end{array}$ & 0.808 & & & & \\
\hline
\end{tabular}

To analyze the discriminant validity, latest technique HTMT test were run. HTMT technique was developed by (Henseler et al., 2014), furthermore (Kline, 2011) indicates that the HTMT threshold should be below $<0.85$, whereas (Gold et al., 2001) indicates that the discriminant validity lower than $<0.90$ is acceptable. To achieve this threshold only 2 indicators were deleted from the model though $20 \%$ of the indicators are allowed to delete (Hair et al., 2017).

Table 3 indicates that the discriminant validity has been achieved between all the constructs, where all the indicators immensely loaded on their respective constructs below HTMT.90 (Gold et al., 2001) If the discriminant validity is not achieved, the research is allowed to remove $20 \%$ of the indicators starting from the lower numbers. The best practice is to check the cross loading numbers to make decision, as shown in table 2 HTMT has been established between all the constructs (Baglin, 2014; Gao and Theobald, 2998).

Table-3. Heterotrait-Monotrait Ratio of Correlations (HTMT)

\begin{tabular}{l|l|l|l|l|l}
\hline & $\begin{array}{l}\text { Quality of } \\
\text { Academic Staff }\end{array}$ & $\begin{array}{l}\text { Student } \\
\text { Expectation }\end{array}$ & $\begin{array}{l}\text { University } \\
\text { Facilities }\end{array}$ & $\begin{array}{l}\text { University } \\
\text { Image }\end{array}$ & $\begin{array}{l}\text { University } \\
\text { Location }\end{array}$ \\
\hline Overall Student Satisfaction & & & & & \\
\hline Quality of Academic Staff & 0.822 & & & & \\
\hline Student Expectation & 0.892 & 0.892 & & & \\
\hline University Facilities & 0.827 & 0.705 & 0.748 & & \\
\hline University Image & 0.797 & 0.813 & 0.870 & 0.708 & \\
\hline University Location & 0.895 & 0.791 & 0.762 & 0.758 & 0.826 \\
\hline
\end{tabular}

To further measure discriminant validity bootstrapping resampling technique is applied to investigate whether the hypothesis is supported.

Figure-2. Bootstrapping Summary 


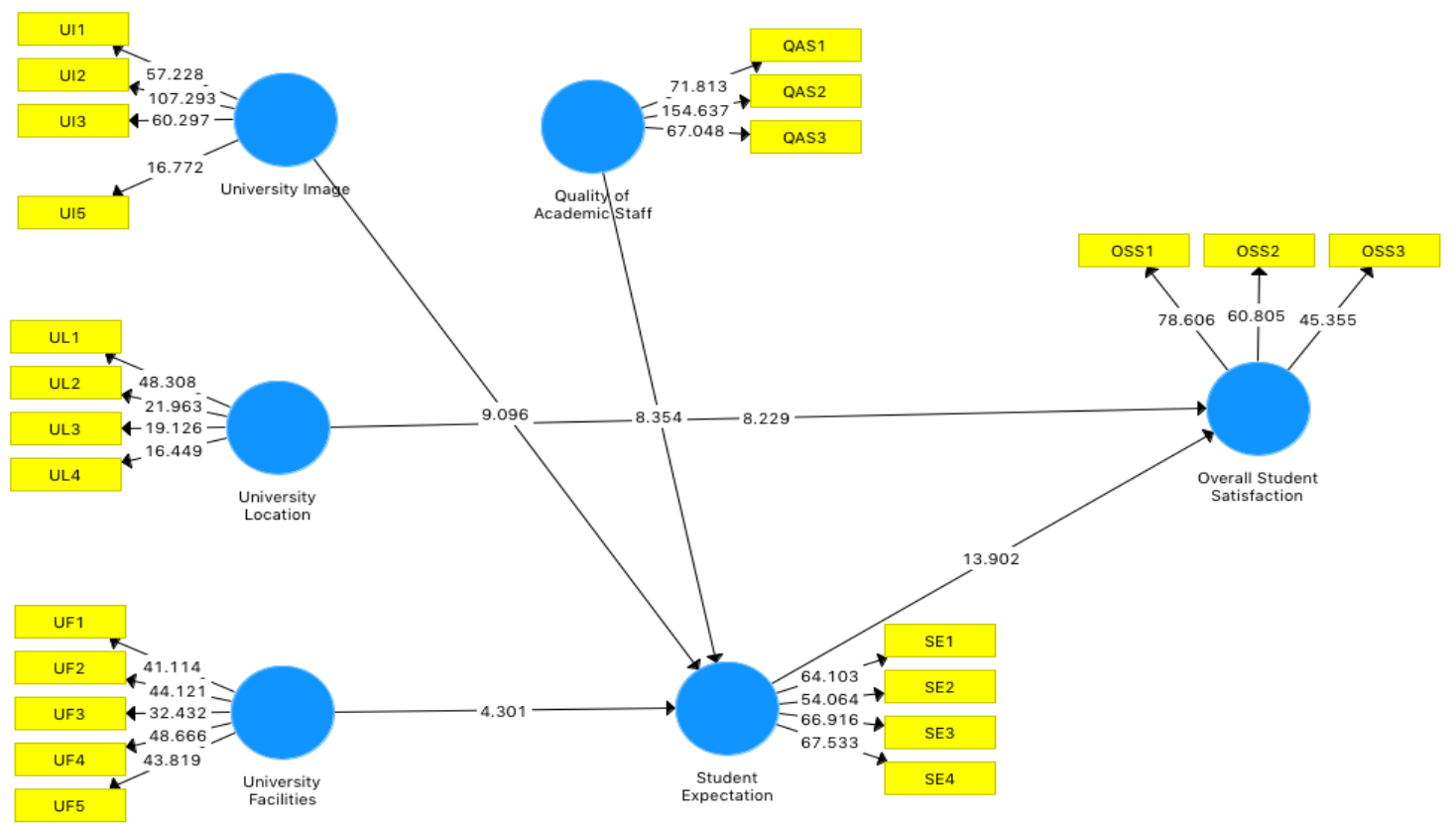

Table-4. Bootstrapping Summary

\begin{tabular}{l|l|l|l|l}
\hline & Standard Deviation & T Statistics & P Values & Supported? \\
\hline University Location -> Overall Student Satisfaction & 0.352 & 8.229 & 0.00 & Yes \\
\hline Quality of Academic Staff -> Student Expectation & 0.435 & 8.354 & 0.00 & Yes \\
\hline University Image -> Student Expectation & 0.346 & 9.096 & 0.00 & Yes \\
\hline University Facilities -> Student Expectation & 0.182 & 4.301 & 0.00 & Yes \\
\hline Student Expectation -> Overall Student Satisfaction & 0.555 & 13.902 & 0.00 & Yes \\
\hline
\end{tabular}

As shown in table 4 that all the hypothesis are supported. The independent variables have a significant impact on the overall student satisfaction. University location role has been tested through the mediating role, which resulted not significant. University role was implemented direct and significant effect on overall student satisfaction. University facilities, quality of academic staff and university image impact were tested direct and through the mediator. The direct impact was not significant and the impact through the student expectation is more significant (Bates et al., 2017).

As shown in figure 2 that all the variables (university image, location, facilities, and student expectation) has a significant relationship with overall student satisfaction. University image has significant and positive relationship on student expectation; University location has significant and positive relationship on overall student satisfaction; University facilities have a significant positive relationship to student expectation; There is a significant positive relationship between student expectation and overall student satisfaction.

The independent sampling t-test measure the mean of two groups, the data has been divided into 2 groups Malaysia and Pakistan. It is also called two sample t-test, in the process of independent t-test the null hypotheses measures the population mean from 2 unrelated groups. If the population means are not equal the null hypotheses can be rejected with the replacement of alternative hypothesis (McLeay et al., 2017). T-test is mainly used for distributed data, also t-test is related to t-distribution family (Abdulwahid et al., 2018). Independent sample t-test was applied to measure the student satisfaction level of comparison in Malaysia and Pakistan.

Table 5 results indicate that the university image in Malaysia $(m=3.9545)$ and Pakistan $(m=3.9364)$ has less significant difference on the university student satisfaction. University students in Malaysia and Pakistan have less impact focus towards university image that will impact the student satisfaction.

However, the results in Table 5 indicate that university location also has an impact on student satisfaction in Malaysia $(m=3.7182)$ and in Pakistan $(m=3.6697)$. Which has a clear indication that the significance is less in Pakistan and Malaysian students almost have same level of requirement on university location that impacts the student satisfaction.

Quality of academic staff in Malaysia $(m=3.6641)$ and Pakistan $(m=3.8283)$ analysis that quality of academic staff has a significant direct impact on the student satisfaction level with the Sig (2-tailed=0.092). This indicates that the students in Malaysia and Pakistan have a direct impact on quality of academic staff.

University facilities have a high impact on student satisfaction in Malaysia $(m=4.1788)$ and Pakistan (3.7212) with Sig. (2-Tailed=0.0000) value. Since our t-value is 4.439 and the Sig (2-Tailed) p value is $<0.05$. Anytime when our $\mathrm{p}$ value is less than 0.05 which it is in this case we we can reject the null and we can conclude that our t-test has fallen into the rejection regions and finally based on this because we can reject the null we can conclude that there is a significant evidence to support our research proposal that university facilities does actually affect the student satisfaction. 
Table-5. Independent sampling t-test Showing Difference in the Mean Score of The Variables of Student Satisfaction in Malaysian and Pakistan Universities

\begin{tabular}{|c|c|c|c|c|c|c|c|}
\hline Variables & Universities & $\mathbf{N}$ & Mean & S.D. & $t$ & df & Sig. (2-Tailed) \\
\hline University Image & $\begin{array}{l}\text { Pakistan } \\
\text { Malaysia }\end{array}$ & $\begin{array}{l}264 \\
132\end{array}$ & $\begin{array}{l}3.9364 \\
3.9545\end{array}$ & $\begin{array}{l}.90367 \\
.85947\end{array}$ & 0.192 & 394 & 0.848 \\
\hline University Location & $\begin{array}{l}\text { Pakistan } \\
\text { Malaysia }\end{array}$ & $\begin{array}{l}264 \\
132\end{array}$ & $\begin{array}{l}3.6697 \\
3.7182\end{array}$ & \begin{tabular}{|l|}
.88896 \\
.85746
\end{tabular} & 0.518 & 394 & 0.605 \\
\hline Quality of Academic Staff & $\begin{array}{l}\text { Pakistan } \\
\text { Malaysia }\end{array}$ & $\begin{array}{l}264 \\
132 \\
\end{array}$ & $\begin{array}{l}3.6641 \\
3.8283\end{array}$ & $\begin{array}{l}1.03304 \\
.84255\end{array}$ & 1.691 & 313.67 & 0.092 \\
\hline University Facilities & $\begin{array}{l}\text { Pakistan } \\
\text { Malaysia }\end{array}$ & $\begin{array}{l}264 \\
132 \\
\end{array}$ & $\begin{array}{l}3.7212 \\
4.1788\end{array}$ & $\begin{array}{l}1.08743 \\
.90064\end{array}$ & 4.439 & 309.63 & 0.000 \\
\hline Student Expectations & $\begin{array}{l}\text { Pakistan } \\
\text { Malaysia }\end{array}$ & $\begin{array}{l}264 \\
132 \\
\end{array}$ & $\begin{array}{l}3.7595 \\
3.8674 \\
\end{array}$ & $\begin{array}{l}.96586 \\
.84508 \\
\end{array}$ & 1.141 & 295.27 & 0.255 \\
\hline Overall Student Satisfaction & $\begin{array}{l}\text { Pakistan } \\
\text { Malaysia }\end{array}$ & $\begin{array}{l}264 \\
132 \\
\end{array}$ & $\begin{array}{l}3.3763 \\
3.4848 \\
\end{array}$ & $\begin{array}{l}.87919 \\
.71381 \\
\end{array}$ & 1.318 & 314.87 & 0.188 \\
\hline
\end{tabular}

University facilities is the main variable that analysis has determined from the results that the students in Malaysia and Pakistan care more about university facilities while and during the selection of university. However, students in Pakistan have raised concerns as analyzed from the results that universities in Pakistan are lacking facilities (electricity break-down, free Wi-Fi, digital library). Whereas universities in Malaysia are keen upgrade their digital libraries facilities. The means results are clear that the student expectation played a mediation role, results analyzed that Malaysian student expectation (3.8674) is significantly higher than students in Pakistan (3.7595) with (2-Tail=0.255). We were able to use t-test for independent means to show that our research hypothesis was significant in this case and that there is a significant difference between student satisfaction in Malaysia and Pakistan

The hypothesis value of University facilities is below 0.05 which mean the difference of university facilities between Malaysia and Pakistan is statistically significant, which is $(\mathrm{p}=0.00)$ and it is highly significant.

\section{Conclusion}

The study concluded that students were satisfied based on the variable results found in data analysis. However, t-test analysis indicates that It has been proved from the data analysis that the university facilities affect the student satisfaction more in Malaysia (mean=4.1788) than Pakistan (mean =3.7212). In highly competitive global educational Malaysian market the students in Malaysia have high expectations towards university facilities on student satisfaction(Marimon, Mas-Machuca, Berbegal-Mirabent, \& Llach, 2017). Whereas the student satisfaction varies in Pakistan across most of the universities, the student expectations towards university facilities are low in Pakistan. Results indicate that the student satisfaction towards university facilities in Malaysia has a direct high impact, whereas the students in Pakistan the university facilities impact is lesser (Rahman et al., 2017)

The results indicate that there was a significant difference was found in university facilities provided in Malaysia universities than universities in Pakistan. Malaysian students are more satisfied with the facilities provided by universities. Whereby, students in Pakistan were dis-satisfied with the university facilities provided to them. According to Siddiqi (2018) public sector universities in Pakistan are lacking proper university facilities that are basic requirement for university education level. Universities in Sindh and Balochistan are having a major electricity back-out issue, which is causing the students to concentrate on their studies. Government of Pakistan will require to investigate and issue funds to these universities (Arif et al., 2017; Butt and Rehman, 2010).

Arif et al. (2017) suggested that the universities in rural areas of Pakistan need more attention and funding's. The universities in Malaysia are equipped with mainly facilities (digital library, common study areas, accommodation and proper transportation for local and international students (Yusoff et al., 2015). According to Khalil-ur-rehman and Farooq (2018) that mainly universities in Pakistan are lacking to provide university facilities to students. However, private universities are investing more on student facilities and learning environment.

The study has also revealed that the university image, quality of academic staff and university facility have a high impact on student expectation. However, the brand image name has also significant impact on the student satisfaction in Malaysia and Pakistan. According to Saleem et al. (2017) university image effect the overall student satisfaction. It has also been analyzed that the significance of university image and brand name has a positive impact on A grade students in Malaysia (Ali et al., 2016).

Quality of academic staff helps students support students throughout the study duration and future career counseling. It has also impact in such word of mouth way that students will socialize positive or negative way. Though the faculty teachers spend more time with their students for their career counseling and growth (Munir, 2018). This research has highlighted the comparative factors from the final data analyses that the university facilities require more attention and focus in the Pakistan and Malaysia. Though, the faculties are lot enhanced in Malaysia, which leads a sample to universities in Pakistan to investigate the factors and work on these factors to improve the quality of education and reach the student satisfaction threshold (Tsedzah and Obuobisa-Darko, 2015). 


\section{Recommendation}

Most of the Malaysian universities are fully equipped with all the facilities that are required in learning and teaching purpose. Facilities include (digital library, free Wi-Fi, common study areas, social discussion area and air condition for student). These facilities have direct and indirect impact on student's overall satisfaction. Whereby in Pakistan the mostly universities are lacking with these facilities, one of the major issue which is the core feature is electricity blackout, which interrupts all the facilities to operate. Though some of the private universities have backup electricity generators/UPS devices but these universities are expensive for all students to afford study. One of the major values that universities in Pakistan will need to improve is the university facilities with the support of the Government of Pakistan (Wallance, 1999; Wilkins et al., 2012).

Malaysian Government has played a huge role in the success to attract international students to Malaysia. It helped to bloom Malaysian economy in south east Asia. Universities in Pakistan will need to collaborate with the Government and work together to improve university facilities. However, admission process has drastically decreased and this cause decrease in number of students in Malaysia. Malaysian Government has taken this challenge to improve the quality and admission process that will help to ease the visa process to international students. It has been a huge discussion and concerns that investigate the factors that are effecting the decreases in international student numbers in Malaysia, which has impacted the Malaysia economy as well.

Furthermore, Pakistan Government has brought some projects to offer scholarship in Pakistan. The ratio of international students is very less and medical science course have scholarships and students from gulf countries. Public universities in Pakistan require prompt attention from government to provide some funding's to universities that public universities will improve their standards to attract more international students in Pakistan, which later will help to grow country's economy.

\section{Reference}

Abdulwahid, A. M., Hanafiah, J. M., Addulsalam, A.-M. R., Sann, L. M., Abdu, S. M., Abdo, R. A.-D., S. and Kadir, S. H. (2018). Relationships among perceived quality of healthcare services, Satisfaction and behavioural intentions of international students in kuala lumpur, Malaysia, A cross-sectional study. BMJ Open: Available: https://doi.org/10.1136/bmjopen-2017-021180

Ahmad, S. Z. (2015). Evaluating student satisfaction of quality at international branch campuses. Assessment and Evaluation in Higher Education, 40(4): 488-507. Available: https://doi.org/10.1080/02602938.2014.925082

Ajayi, M. (2015). Students ' satisfaction with hostel facilities in federal university of. 11(34): 402-15.

Al-hawari, M. A. and Mouakket, S. (2010). The influence of technology acceptance model (tam) factors on students' e-satisfaction and e-retention within the context of uae e-learning. Education Business and Society ,Contemporary Middle Eastern Issues, 3(4): 299-314. Available: https://doi.org/10.1108/17537981011089596

Ali, F., Zhou, Y., Hussain, K., Nair, P. K. and Ragavan, N. A. (2016). Does higher education service quality effect student satisfaction, image and loyalty? A study of international students in malaysian public universities. Quality Assurance in Education, 24(1): 70-94. Available: https://doi.org/10.1108/QAE-02-2014-0008

Alrasheedi, M. and Capretz, L. F., 2013. "Determination of critical success factors affecting mobile learning, A meta-analysis approach." In IEEE International Conference on Teaching, Assessment and Learning for Engineering (TALE), 14(August). pp. 262-67.

Alshehri, A. F. (2017). Student satisfaction and commitment towards a blended learning finance course, A new evidence from using the investment model. Research in International Business and Finance, 41: 423-33. Available: https://doi.org/10.1016/j.ribaf.2017.04.050

Alves, H. and Raposo, M. (2009). The measurement of the construct satisfaction in higher education. Service Industries Journal, 29(2): 203-18. Available: https://doi.org/10.1080/02642060802294995

Amin, M. and Isa, Z. (2008). An examination of the relationship between service quality perception and customer satisfaction, A sem approach towards malaysian islamic banking. International Journal of Islamic and Middle Eastern Finance and Management, 1(3): 191-209. Available: https://doi.org/10.1108/17538390810901131

Arif, M., Ameen, K. and Rafiq, M. (2017). Assessing distance education students satisfaction with web-based services, A Pakistani's perspective. Online Information Review, 41(2): 202-18. Available: https://doi.org/10.1108/OIR-07-2016-0172

Awang, Z., Ahmad, J. H. and Zin, N. M., 2010. "Modelling job satisfaction and work commitment among lecturers, A case of uitm kelantan." In Proceedings of the Regional Conference on Statistical Science (RCSS '10), (January 2015). pp. 241-55.

Baglin, J. (2014). Improving your exploratory factor analysis for ordinal data, A demonstration using factor. Practical asessment. Research and Evaluation, 19(5): 1-14. Available: https://doi.org/10.1146/annurev.psych.53.100901.135239

Ball, R. and Chik, R. (2001). Early employment outcomes of home and foreign educated graduates - the Malaysian experience. Higher Education, 42: 171-89. Available: https://doi.org/10.1023/a:1017579415737

Bates, E. A., Kaye, L. K. and McCann, J. J. (2017). A snapshot of the student experience: exploring student satisfaction through the use of photographic elicitation. Journal of Further and Higher Education, 9486(October): 1-14. Available: https://doi.org/10.1080/0309877X.2017.1359507 
Brown, R. M. and Mazzarol, T. W. (2009). The importance of institutional image to student satisfaction and loyalty within higher education. Higher Education, 58(1): 81-95. Available: https://doi.org/10.1007/s10734-0089183-8

Butt, B. Z. and Rehman, K. U. (2010). A study examining the students satisfaction in higher education. Procedia, Social and Behavioral Sciences, 2(2): 5446-50. Available: https://doi.org/10.1016/j.sbspro.2010.03.888

Buzdar, M. F., Janjua, S. Y. S. Y., Khurshid, M. A. M. A., Farooq, M., Janjua, S. Y. S. Y. and Khurshid, M. A. M. A. (2016). Customer-based brand equity and firms' performance in the telecom industry. International Journal of Services and Operations Management, 25(3): $334 . \quad$ Available: https://doi.org/10.1504/IJSOM.2016.079516

Byrne, B. M. (2016). Structural equation modeling with AMOS, Basic concepts, applications and programming. Routledge.

Choy, S. C., Yim, J. S. C. and Tan, P. L. (2017). Student's perceptions of quality learning in a Malaysian university - a mixed method approach. Quality Assurance in Education, 25(4): 500-15. Available: https://doi.org/10.1108/QAE-12-2016-0088

Eva, E. O., Islam, M. Z., Mosaddek, A. S. M., Rahman, M. F., Rozario, R. J., Iftekhar, A. F. M. H. and Haque, M. (2015). Prevalence of stress among medical students, A comparative study between public and private medical schools in Bangladesh. BMC Research Notes, 8(1): 1-7. Available: https://doi.org/10.1186/s13104015-1295-5

Gao, G. R. and Theobald, K. B. (2998). A refinement of the htmt program execution model the htmt program execution model ( extended abstract ) y jet propulsion laboratory, (september).

Gold, A. H., Malhotra, A. and Segars, A. H. (2001). Knowledge management, An organizational capabilities perspective. Journal of Management, 18(1): 185-214. Available: http://doi.org/10.1080/07421222.2001.11045669

Hair, J. F., Hult, T. M., Ringle, C. M., Sarstedt, M. and Sarstedt, M. (2017). A primer on partial least square structural equation modeling (pls-sem). Sage Publication.

Hanssen, T. E. S. and Solvoll, G. (2015). The importance of university facilities for student satisfaction at a norwegian university. Facilities. 33: 744-59. https://doi.org/10.1108/F-11-2014-0081

Henseler, J., Ringle, C. M. and Sarstedt, M. (2014). A new criterion for assessing discriminant validity in variancebased structural equation modeling. Journal of the Academy of Marketing Science, 43(1): 115-35. Available: https://doi.org/10.1007/s11747-014-0403-8

Hussein, A. I. and Abdul, R. I. D. (2012). Structural equation models of management and decision-making styles with job satisfaction of academic staff in Malaysian research university. International Journal of Educational Management, 26(7): 616-45. Available: https://doi.org/10.1108/09513541211263700

Ijaz, A., Irfan2, S. M., Shahbaz2, S., Awan2, M. and Sabir3, M. (2011). An empirical model of student satisfaction. Case of Pakistani Public Sector Business Schools: 91-114.

Khalil-ur-rehman, F. and Farooq, M. (2018). Deployment of mobile learning in advanced education foundations. 18(6).

Khan, M. and Nawaz, M. (2011). Teaching quality in higher education, What do we need to improve? Interdicilinary Journal of Research in Business, 1(4): 37-42. Available: https://doi.org/10.1519/JSC.0b013e318196b784

Kline, R. B. (2011). Principles and practice of structural equation modeling. Guilford publications.

Krejcie, R. V. and Morgan, D. W. (1970). Determining sample size for research activities. Educational and Psychological Measurement, 30: 607-10.

Lam, T. T. (2010). A study of job stress on job satisfaction among virtual workers in information technology. An Empirical Study: 1-142.

Mansori, S., Vaz, A. and Ismail, Z. M. M. (2014). Service quality, Satisfaction and student loyalty in Malaysian private education. Asian Social Science, 10(7): 57-66. Available: https://doi.org/10.5539/ass.v10n7p57

McLeay, F., Robson, A. and Yusoff, M. (2017). New applications for importance-performance analysis (ipa) in higher education, Understanding student satisfaction. Journal of Management Development, 36(6): 780 800. Available: https://doi.org/10.1108/JMD-10-2016-0187

Munir, F. F. A. (2018). Reliability and validity analysis on the relationship between learning space, studentâ\&\#128;\&\#153, S satisfaction and perceived performance using smart-pls. International Journal of Academic Research in Business and Social Sciences, 8(1): 775-86. Available: https://doi.org/10.6007/IJARBSS/v8-i1/3847

Napitupulu, D., Rahim, R., Abdullah, D., Setiawan, M., Abdillah, L., Ahmar, A. and Pranolo, A. (2018). Analysis of student satisfaction toward quality of service facility. Journal of Physics: Available: https://doi.org/10.1088/1742-6596/954/1/012019

Nunnally, J. (1978). Psychometric Theory. 2nd edn: McGraw-Hill, New York: NY.

Rahman, M. S., Hassan, H., Osman-Gani, A., Abdel, F. F. A. M. and Anwar, M. A. (2017). Edu-tourist's perceived service quality and perception - the mediating role of satisfaction from foreign students' perspectives. Tourism Review, 72(2): 156-70. Available: https://doi.org/10.1108/TR-12-2016-0057

Riera, G. J., Ardid, R. M., Vidaurre, G. A. J., Meseguer-Dueñas, J. M. and Gómez-Tejedor, J. A. (2018). Students' perception of auto-scored online exams in blended assessment, Feedback for improvement. Educación XX1, 21(2): 79-103. Available: https://doi.org/10.5944/educxx1.19559 
Saleem, S. S., Moosa, K., Imam, A. and Khan, R. A. (2017). Service quality and student satisfaction, The moderating role of university culture, Reputation and price in education sector of Pakistan. Iranian Journal of Management Studies, 10(1): 237-58. Available: https://doi.org/10.22059/ijms.2017.217335.672304

Siddiqi, A. (2018). Mediating role of students' engagement to their classes. Asian Association of Open Universities Journal: Available: https://doi.org/10.1108/AAOUJ-04-2018-0017

Subrahmanyam, A. (2017). Relationship between service quality, satisfaction, motivation and loyalty, A multidimensional perspective. Quality Assurance in Education, 25(2): 171-88. Available: https://doi.org/10.1108/QAE-04-2013-0016

Sultan, P. and Wong, H. Y. (2013). Antecedents and consequences of service quality in a higher education context, A qualitative research approach. Quality Assurance in Education, 21(1): 70-95. Available: https://doi.org/10.1108/09684881311293070

Temizer, L. and Turkyilmaz, A. (2012). Implementation of student satisfaction index model in higher education institutions. Procedia - Social and Behavioral Sciences, 46: 3802-06. Available: https://doi.org/10.1016/j.sbspro.2012.06.150

Teo, T. and Wong, S. L. (2013). Modeling key drivers of e-learning satisfaction among student teachers. Journal of Educational Computing Research, 48(1): 71-95. Available: https://doi.org/10.2190/EC.48.1.d

Teo, T., Lee, C. B., Chai, C. S. and Wong, S. L. (2009). Assessing the intention to use technology among pre-service teachers in singapore and malaysia, A multigroup invariance analysis of the technology acceptance model (tam). Computers and Education, 53(3): 1000-09. Available: https://doi.org/10.1016/j.compedu.2009.05.017

Tsedzah, V. A. and Obuobisa-Darko, T. (2015). Assessing students' satisfaction, An approach to help improve services rendered to university students. European Journal of Business and Management, 7(5): 115-23.

Turkyilmaz, A., Temizer, L. and Oztekin, A. (2018). A causal analytic approach to student satisfaction index modeling. Annals of Operations Research, 263(1-2): 565-85. Available: https://doi.org/10.1007/s10479016-2245-X

Ulyani, M. N. N., Aini, Y. N. and Zainul, A. N. (2011). Student residential satisfaction in research universities. Journal of Facilities Management, 9(3): 200-12. Available: https://doi.org/10.1108/14725961111148108

Wallance (1999). Measuring student satisfaction in public and private universities in Pakistan. 13(3).

Weerasinghe, I. M. S. and Fernando, R. L. S. (2018). Critical factors affecting students' satisfaction with higher education in sri lanka. Quality Assurance in Education, 26(1): 115-30. Available: https://doi.org/10.1108/QAE-04-2017-0014

Wilkins, S., Stephens, B. M. and Huisman, J. (2012). Student satisfaction and student perceptions of quality at international branch campuses in the United Arab Emirates. Journal of Higher Education Policy and Management, 34(5): 543-56. Available: https://doi.org/10.1080/1360080X.2012.716003

Yusoff, M., McLeay, F. and Woodruffe-Burton, H. (2015). Dimensions driving business student satisfaction in higher education. Quality Assurance in Education, 23(1): 86-104. Available: https://doi.org/10.1108/QAE08-2013-0035

Zhai, X., Gu, J., Liu, H., Liang, J.-C. and Tsai, C.-C. (2017). An experiential learning perspective on students' satisfaction model ina flipped classroom context. Educational Technology \& Society, 20(1): 198-210. 